\title{
PERUBAHAN PERSEPSI REMAJA SETELAH DIBERIKAN PENDIDIKAN KESEHATAN MENGGUNAKAN MEDIA AUDIO VISUAL TENTANG FAKTOR RISIKO DIABETES MELLITUS TIPE 2
}

\author{
Maria Diah CT, Tri Cahyo S, Wiwin Martiningsih \\ Poltekkes Kemenkes Malang, Jl. Besar Ijen 77 C Malang \\ e-mail: maria_dityas@yahoo.com
}

\begin{abstract}
Wrong Perception is one of the risk factors of Diabetes Mellitus (DM) type 2 will make adolescent to do unhealthy lifestyle that leads to DM disease. Increasing knowledge through health education is expected to increase the perception. The purpose of research was to analyze adolescent's perceptions changing after was given health education using audio visual media about risk factors of type 2 Diabetes Mellitus. The method in this research was experimental research with QuasiExperimental design pretest-posttest. The sample consisted of 128 respondents, 64 respondents in control group and 64 respondents in the experimental group. Sampling was done by purposive sampling. The results showed an increasing perceptions average 2.31 in control group. In experimental group increased a perceptions average 3.44. Further analysis showed that health education using audio-visual media is more effective in improving perceptions. The conclusion of this research showed that using audio-visual media is more effective to increase the perception. Audio-visual media provide a more attractive appearance, so that there is a dynamic movement to attract the attention. The research recommended an increasing in preventive and promotive diabetes type 2 through health education and activities around school (SMU).
\end{abstract}

Keywords: perception, risk factors for diabetes type 2, health education, audio-visual

\begin{abstract}
Abstrak: Persepsi yang salah mengenai faktor risiko Diabetes Mellitus (DM) tipe 2 akan mengakibatkan remaja melakukan gaya hidup tidak sehat yang mengarah terjadi penyakit DM. Peningkatan pengetahuan melalui pendidikan kesehatan diharapakan bisa meningkatkan persepsi. Tujuan penelitian untuk menganalisis perubahan persepsi remaja tentang faktor risiko DM tipe 2 setelah diberikan pendidikan kesehatan menggunakan media audio visual. Metode penelitian ini merupakan penelitian eksperimental dengan desain Quasi-Experimental Pretest-Posttest. Sampel penelitian terdiri dari 128 responden, 64 responden pada kelompok kontrol dan 64 responden pada kelompok perlakuan. Pengambilan sampel dilakukan dengan cara purposive sampling. Hasil penelitian menunjukkan pada kelompok kontrol terjadi peningkatan rata-rata persepsi 2,31. Pada kelompok perlakuan terjadi peningkatan rata-rata persepsi 3,44. Analisis lebih lanjut menunjukkan pendidikan kesehatan menggunakan media audio visual lebih efektif dalam meningkatkan persepsi. Kesimpulan dari penelitian ini adalah penggunaan media audio visual lebih efektif untuk meningkatkan persepsi. Media audio visual memberikan gambaran yang lebih menarik, terdapat gerak yang dinamis sehingga menarik minat untuk memperhatikan. Rekomendasi penelitian ini peningkatan tindakan preventif dan promotif DM tipe 2 melalui pendidikan kesehatan dan kegiatan dalam lingkungan sekolah (SMU).
\end{abstract}

Kata kunci : persepsi, faktor risiko DM tipe 2, pendidikan kesehatan, audio visual 


\section{PENDAHULUAN}

Diabetes mellitus (DM) merupakan penyakit metabolik dimana kemampuan tubuh untuk menggunakan glukosa, lemak dan protein terganggu, berhubungan dengan kurangnya insulin atau resistensi insulin (Dunning, 2003). DM merupakan penyakit sistemik kronik dengan karakteristik kurangnya insulin atau penurunan kemampuan tubuh dalam menggunakan insulin. Seluruh penderita DM yang paling banyak adalah DM tipe 2, yaitu mencapai $90 \%-95 \%$ dan didiagnosa Dm setelah usia 40 tahun (Black \& Hawk, 2005). Peningkatan prevalensi penyakit DM ditunjukkan dari hasil Riskesdas 2007, dimana terdapat peningkatan angka dari $1,7 \%$ di tahun 1985 menjadi 5,7\% di tahun 2007 . Distribusi usia penderita DM di daerah sedang berkembang lebih banyak terjadi pada kelompok usia > 30 tahun (IDF). Kelompok usia tersebut menunjukkan bahwa penyakit DM banyak terjadi pada usia produktif. Dampak fisiologis dan psikologis dari penyakit DM akan membuat penderita di usia tersebut menjadi tidak produktif bahkan bisa menjadi beban keluarga dan lingkungan.

Saat ini usia remaja dikenal mulai rawan terkena penyakit DM karena melakukan pola hidup tidak sehat. Antara lain gaya hidup tidak sehat, mengkonsumsi makanan berlemak seperti junk food dan soft drink. Kurang berolahraga, dan kebiasaan merokok juga bisa memicu penyakit diabetes. Apalagi, seseorang yang mengkonsumsi makanan berkalori tinggi lebih banyak. Perilaku yang dilakukan mulai usia remaja dan dilakukan sampai dengan dewasa memungkinkan remaja terkena penyakit DM.

Seseorang menunjukkan perilaku sehat dalam hidupnya diawali dari persepsi individu terhadap sesuatu yang akan dilakukan. Persepsi merupakan praktik/tindakan tingkat pertama yang diambil dari domain perilaku manusia yang ketiga yaitu psikomotor setelah kognitif dan afektif menurut Benyamin Bloom (1908) dalam Notoadmodjo (2007, hlm.145). Adanya persepsi yang salah/negatif dari individu tentang faktor risiko DM tipe 2 akan membuat remaja melakukan gaya hidup yang tidak sehat yang memungkinkan remaja suatu saat akan mengalami DM.

IDF (2009) memperkirakan pada tahun 2030 terjadi peningkatan jumlah penderita DM dari tahun 2010 yaitu 7 juta menjadi 12 juta orang. Peningkatan angka kejadian/jumlah penderita DM dapat disebabkan oleh beberapa faktor, antara lain adalah banyaknya faktor risiko penyakit DM tipe 2 yang muncul di masyarakat. Keyakinan seseorang terhadap suatu penyakit mempengaruhi orang tersebut dalam melakukan perilaku sehat. Persepsi yang baik mengenai faktor risiko DM tipe 2 akan membantu masyarakat dalam mengontrol faktor risiko DM yang dapat dirubah. Upaya mencegah terjadi peningkatan kejadian DM tiep 2 di tahun 2030 nanti, bisa dilakukan saat ini dengan memberikan pendidikan kesehatan kepada remaja mengenai faktor risiko DM tipe dengan tujuan dapat merubah gaya hidup. Pendidikan kesehatan yang diberikan diharapkan dapat meningkatkan persepsi sehingga remaja dapat memiliki perilaku sehat. Peningkatan persepsi faktor risiko DM dapat dilakukan dengan penambahan informasi pada masyarakat, salah satunya dengan cara edukasi menggunakan media audio visual.

Berdasaran uraian tersebut di atas maka perlu diteliti tentang perubahan persepsi remaja setelah diberikan pendidikan kesehatan dengan media audio visual tentang factor risiko DM tipe. Tujuan penelitian tersebut adalah menganalisis peningkatan persepsi remaja tentang faktor risiko diabetes mellitus tipe 2 setelah diberikan pendidikan kesehatan menggunakan media audio visual.

\section{METODE PENELITIAN}

Pada penelitian ini menggunakan Quasi Experimental Design dengan pendekatan Non Randomized Pretest - Posttest Control Group Design. siswa kelas X di SMUN 1 dan SMUN 2 kota Blitar dengan jumlah populasi kira-kira 800 siswa. Sampel adalah siswa kelas $\mathrm{X}$ di SMUN I kota Blitar. Besar sampel pada penelitian ini adalah 128 siswa. Sampel dipilih dengan teknik purposive sampling. Sampel dibagi menjadi 2 yaitu 64 siswa untuk kelompok kontrol yaitu siswa kelas X SMUN 2 Kota Blitar dan 64 siswa untuk kelompok perlakuan yaitu siswa kelas X SMUN 1 Kota Blitar.

Variabel bebas penelitian ini adalah pendidikan kesehatan menggunakan media audio visual sedangkan variabel terikat penelitian ini adalah persepsi remaja tentang faktor risiko DM tipe 2. Data mengenai persepsi faktor risiko DM sebelum dan sesudah pendidikan kesehatan diukur dengan menggunakan kuesioner yang dikembangkan 
dari FIND RISK DM Type-2. Pertanyaan mengenai persepsi terdiri dari 13 pertanyaan menggunakan skala likert.

Perlakuan yang diberikan adalah pendidikan kesehatan dengan media audio visual pada kelompok perlakuan. Sedangkan pada kelompok kontrol dilakukan pendidikan kesehatan menggunakan leaflet. Pelaksanaan teknik pendidikan kesehatan ini bertujuan untuk terjadinya perubahan persepsi.

Pelaksanaan penelitian ini dilakukan pada 2 kelompok responden. Setiap kelompok beranggotakan 64 responden. Setelah ditentukan sampel, maka repsponden dibagi menjadi 2 kelompok. Setelah responden menyatakan bersedia kemudian dilakukan pengukuran persepsi faktor risiko DM tipe 2 menggunakan kuesioner untuk mendapatkan data sebelum dilakukan pendidikan kesehatan. Kemudian kelompok perlakuan diberikan pendidikan kesehatan tentang factor risiko DM tipe 2 dengan media audio visual. Sedangkan pada kelompok kontrol dilakukan pendidikan kesehatan menggunakan leaflet. Waktu yang digunakan untuk pendidikan kesehatan 40 menit. Pendidikan kesehatan yang diberikan meliputi pengertian, penyebab, faktor risiko dan tanda gejala DM tipe 2. Mengukur persepsi faktor risiko DM tipe 2 menggunakan kuesioner sesudah dilakukan pendidikan kesehatan pada kelompok kontrol dan kelompok perlakuan satu minggu kemudian.

Untuk mengidentifikasi perubahan sebelum dan sesudah pendidikan kesehatan dilakukan analisis bivariat uji t 2 sampel berpasangan. Untuk mengetahui perbedaan persepsi kelompok kontrol dengan kelompok perlakuan analisis bivariat uji t 2 sampel bebas. Hasil penelitian ditampilkan dalam bentuk tabel.

\section{HASIL PENELITIAN}

Hasil penelitian meliputi karakteristik responden dan perubahan persepsi sebelum dan setelah dilakukan pendidikan kesehatan tentang faktor risiko DM tipe 2 menggunakan media audio visual.

Karakteristik responden terdiri dari umur, jenis kelamin, suku, riwayat penyakit orangtua, riwayat gemuk dalam keluarga, pengetahuan tentang DM, pengertian DM, riwayat penyakit DM dalam keluarga, penyebab terjadinya DM tipe 2.
Tabel 1.

Distribusi Responden Berdasarkan Umur di SMUN 1 dan SMUN 2 Kota Blitar Agustus 2011

\begin{tabular}{|c|c|c|c|c|c|c|}
\hline \multirow[t]{3}{*}{$\begin{array}{c}\text { Varia } \\
\text {-bel }\end{array}$} & \multicolumn{2}{|c|}{$\begin{array}{c}\text { Kelompo } \\
\text { k } \\
\text { Kontrol } \\
\end{array}$} & \multicolumn{2}{|c|}{$\begin{array}{l}\text { Kelompok } \\
\text { Perlakuan }\end{array}$} & \multirow[t]{3}{*}{$\begin{array}{c}\text { Tota } \\
1\end{array}$} & \multirow[t]{3}{*}{$\%$} \\
\hline & \multicolumn{2}{|c|}{$(n=64)$} & \multicolumn{2}{|c|}{$(n=64)$} & & \\
\hline & $\mathbf{f}$ & $\%$ & $\mathbf{f}$ & $\%$ & & \\
\hline Umur & & & & & & \\
\hline 14 thn & 0 & 0 & 3 & 4.7 & 3 & 2.3 \\
\hline 15 thn & 44 & $\begin{array}{c}68 . \\
8 \\
\end{array}$ & 35 & 54.7 & 79 & $\begin{array}{c}61 . \\
7\end{array}$ \\
\hline 16 thn & 19 & $\begin{array}{c}29 . \\
7\end{array}$ & 26 & 40.6 & 45 & $\begin{array}{c}35 . \\
2\end{array}$ \\
\hline 17 thn & 1 & 1.6 & 0 & 0 & 1 & 0.8 \\
\hline & & & & & 128 & 100 \\
\hline
\end{tabular}

Tabel 2.

Distribusi Responden Berdasarkan Jenis Kelamin di SMUN 1 dan SMUN 2 Kota Blitar Agustus 2011

\begin{tabular}{|c|c|c|c|c|c|c|}
\hline \multirow[t]{3}{*}{ Variabel } & \multicolumn{2}{|c|}{$\begin{array}{c}\text { Kelompok } \\
\text { Kontrol }\end{array}$} & \multicolumn{2}{|c|}{$\begin{array}{c}\text { Kelompo } \\
\text { k } \\
\text { Perlakua } \\
\mathbf{n}\end{array}$} & \multirow[t]{3}{*}{$\begin{array}{c}\text { Tota } \\
1\end{array}$} & \multirow[t]{3}{*}{$\%$} \\
\hline & \multicolumn{2}{|c|}{$(n=64)$} & \multicolumn{2}{|c|}{$(n=64)$} & & \\
\hline & $\mathbf{f}$ & $\%$ & $\mathbf{f}$ & $\%$ & & \\
\hline $\begin{array}{l}\text { Jenis } \\
\text { Kelamin }\end{array}$ & & & & & & \\
\hline Laki-laki & 18 & $\begin{array}{c}28 . \\
1\end{array}$ & 27 & $\begin{array}{c}42 . \\
2\end{array}$ & 45 & $\begin{array}{c}35 . \\
2\end{array}$ \\
\hline $\begin{array}{l}\text { Perempua } \\
n\end{array}$ & 46 & $\begin{array}{c}71 . \\
9\end{array}$ & 37 & $\begin{array}{c}57 . \\
8\end{array}$ & 83 & $\begin{array}{c}64 . \\
8\end{array}$ \\
\hline
\end{tabular}

Tabel 3

Distribusi Responden Berdasarkan Pengertian Diabetes Melitus Di SMUN 1 Dan SMUN 2 Kota Blitar Agustus 2011

\begin{tabular}{|c|c|c|c|c|c|c|}
\hline \multirow[t]{2}{*}{ Variabel } & \multicolumn{2}{|c|}{$\begin{array}{c}\text { Kelompok } \\
\text { Kontrol } \\
(n=64)\end{array}$} & \multicolumn{2}{|c|}{$\begin{array}{c}\begin{array}{c}\text { Kelompok } \\
\text { Perlakuan }\end{array} \\
(\mathbf{n}=64) \\
\end{array}$} & \multirow[t]{2}{*}{$\begin{array}{c}\text { Tot } \\
\text { al }\end{array}$} & \multirow[t]{2}{*}{$\%$} \\
\hline & $\mathbf{f}$ & $\%$ & $\mathbf{f}$ & $\%$ & & \\
\hline \multicolumn{7}{|l|}{ Pengertian DM } \\
\hline $\begin{array}{l}\text { Karena } \\
\text { kelebihan kadar } \\
\text { gula darah }\end{array}$ & 29 & 45.3 & 28 & 43.8 & 57 & 44.5 \\
\hline $\begin{array}{l}\text { Penyakit karena } \\
\text { kekurangan }\end{array}$ & 0 & 0 & 9 & 14.1 & 9 & 7 \\
\hline
\end{tabular}




\begin{tabular}{|c|c|c|c|c|c|c|c|c|c|c|c|c|}
\hline insulin & & & & & & putih & & & & & & \\
\hline \multirow{2}{*}{$\begin{array}{l}\text { Penyakit karena } \\
\text { kerusakan ginjal }\end{array}$} & \multirow[t]{2}{*}{0} & \multirow[t]{2}{*}{0} & \multirow[t]{2}{*}{10} & \multirow[t]{2}{*}{15.6} & \multirow[t]{2}{*}{10} & Tid8k menjawab & 0 & 0 & 1 & 1.6 & 1 & 0.8 \\
\hline & & & & & & & & & & & 128 & 100 \\
\hline $\begin{array}{l}\text { Penyakit } \\
\text { keturunan }\end{array}$ & 0 & 0 & 5 & 7.8 & 5 & 4 & & & & & & \\
\hline Tidak menjawab & 35 & 54.7 & 12 & 18.7 & 47 & 36.7 & & & & & & \\
\hline & & & & & 128 & 100 & & & & & & \\
\hline
\end{tabular}

Tabel 4.5

Tabel 4

Distribusi Responden Berdasarkan anggapan Remaja Penyebab Diabetes Melitus di SMUN 1 dan SMUN 2 Kota Blitar Agustus 2011

\begin{tabular}{|c|c|c|c|c|}
\hline Variabel & $\begin{array}{c}\begin{array}{c}\text { Kelompok } \\
\text { Kontrol }\end{array} \\
(\mathbf{n}=64)\end{array}$ & $\begin{array}{c}\begin{array}{c}\text { Kelompok } \\
\text { Perlakuan }\end{array} \\
(n=64)\end{array}$ & $\begin{array}{c}\text { Tot } \\
\text { al }\end{array}$ & $\%$ \\
\hline & $\%$ & $\%$ & & \\
\hline
\end{tabular}

\begin{tabular}{|c|c|c|c|c|c|c|}
\hline $\begin{array}{l}\text { Anggapan } \\
\text { Remaja tentang } \\
\text { Penyebab DM }\end{array}$ & & & & & & \\
\hline $\begin{array}{l}\text { Banyak } \\
\text { makan/minum } \\
\text { manis }\end{array}$ & 59 & 92.2 & 50 & 78.1 & 109 & 85.1 \\
\hline Hipertensi & 1 & 1.6 & 0 & 0 & 1 & 0.8 \\
\hline $\begin{array}{l}\text { Sering menahan } \\
\text { buang air }\end{array}$ & 1 & 1.6 & 0 & 0 & 1 & 0.8 \\
\hline Keturunan & 2 & 3.1 & 8 & 12.5 & 10 & 7.8 \\
\hline $\begin{array}{l}\text { Tidak menjaga } \\
\text { kesehatan }\end{array}$ & 1 & 1.6 & 3 & 4.7 & 4 & 3.1 \\
\hline Kekurang yodium & 0 & 0 & 1 & 1.6 & 1 & 0.8 \\
\hline Kekurangan air & 0 & 0 & 1 & 1.6 & 1 & 0.8 \\
\hline
\end{tabular}

Distribusi Responden Berdasarkan Riwayat

Keluarga Menderita Diabetes Melitus Di

SMUN 1 Dan SMUN 2 Kota Blitar Agustus 2011

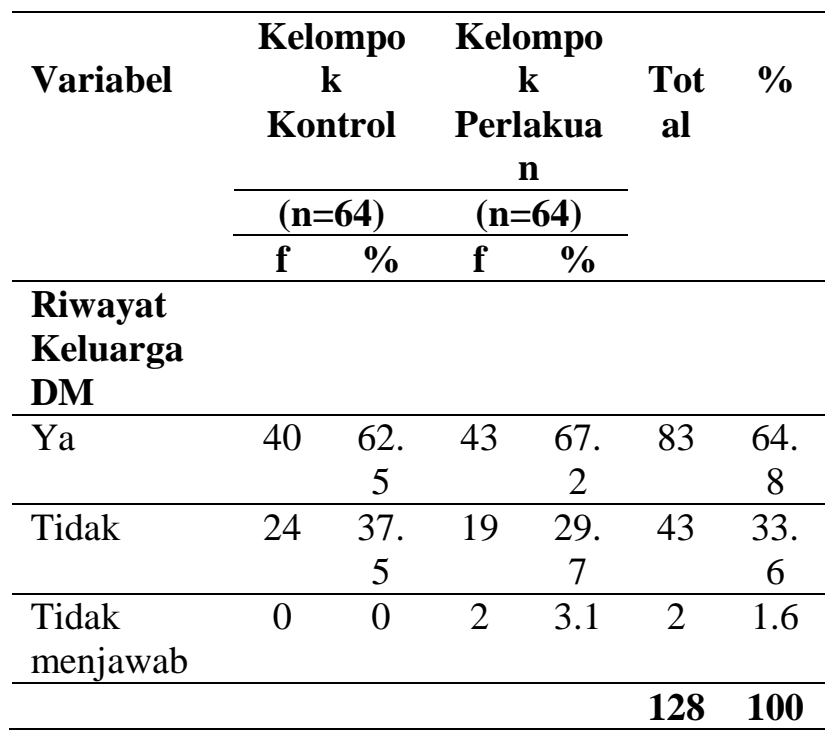

Tabel 6

Perubahan persepsi sebelum dan sesudah diberikan pendidikan kesehatan di SMUN 2 dan SMUN 1 Kota Blitar Agustus 2011

\begin{tabular}{ccccccc}
\hline Variabel & Kelompok & & Rata-rata & SD & t & $p$-value \\
\hline \multirow{3}{*}{ Persepsi } & Kontrol & Sebelum & 37.53 & 2.494 & -5.778 & $0.000^{*}$ \\
\cline { 3 - 7 } & & Sesudah & 39.84 & 3.009 & & \\
\cline { 2 - 7 } & Perlakuan & Sebelum & 38.14 & 3.162 & -7.857 & $0.000^{*}$ \\
\cline { 3 - 7 } & & Sesudah & 41.58 & 3.090 & & \\
\hline
\end{tabular}

*Bermakna pada $\alpha<0,05$

Tabel 7

Perubahan persepsi sesudah diberikan pendidikan kesehatan pada kelompok kontrol dan perlakuan di SMUN 1 Kota Blitar Agustus 2011

\begin{tabular}{ccccc}
\hline Variabel & Rata-rata & SD & t & p value \\
\hline Persepsi & & & & \\
\hline Kontrol & 39.84 & 3.009 & -3.217 & $0.002^{*}$ \\
\hline
\end{tabular}




\begin{tabular}{ccc}
\hline Perlakuan & 41.57 & 3.090 \\
\hline *Bermakna pada $\alpha<0,05$ &
\end{tabular}

Perubahan persepsi sebelum dan sesudah diberikan pendidikan kesehatan ditunjukkan pada tabel 6 , sedangkan perubahan persepsi pada kelompok kontrol dan perlakuan ditunjukkan pada tabel 7.

Tabel 6 menunjukkan hasil analisis data pada kelompok kontrol menunjukkan rata-rata persepsi sebelum diberikan pendidikan kesehatan adalah 37.53 dengan standar deviasi 2.494, sedangkan setelah diberikan pendidikan kesehatan adalah 39.84 dengan standar deviasi 3.009. Analisis selanjutnya menunjukkan adanya perbedaan yang signifikan rata-rata persepsi sebelum dan setelah diberikan pendidikan kesehatan tentang faktor risiko DM tipe 2 pada kelompok kontrol ( $\mathrm{p}$ value < $0,05)$. Hasil analisis data pada kelompok perlakuan menunjukkan rata-rata persepsi sebelum diberikan pendidikan kesehatan adalah 38.14 dengan standar deviasi 3.162, sedangkan setelah diberikan pendidikan kesehatan adalah 41.58 dengan standar deviasi 3.090. Analisis selanjutnya menunjukkan adanya perbedaan yang signifikan rata-rata persepsi sebelum dan setelah diberikan pendidikan kesehatan tentang faktor risiko DM tipe 2 pada kelompok perlakuan ( $\mathrm{p}$ value < $0,05)$.

Tabel 7 menunjukkan Hasil analisis data pada kelompok kontrol menunjukkan rata-rata persepsi adalah 39.84 dengan standar deviasi 3.009 , sedangkan kelompok perlakuan adalah 41.57 dengan standar deviasi 3.090. Analisis selanjutnya menunjukkan adanya peningkatan rata-rata persepsi kelompok yang diberikan pendidikan kesehatan menggunakan media audio visual dibandingkan kelompok yang diberikan pendidikan kesehatan menggunakan leaflet ( $\mathrm{p}$ value $<0,05$ ).

\section{PEMBAHASAN}

\section{Karateristik Responden}

Responden pada penelitian ini terdiri dari siswa kelas X di SMUN 1 dan SMUN 2 Kota Blitar, sehingga umur responden sebagian besar 15 tahun dan 16 tahun. Berdasarkan jenis kelamin, pada kelompok kontrol dan perlakuan sebagian besar perempuan khususnya pada kelompok kontrol (71,9\%). Pengetahuan tentang DM khususnya pengertian dan penyebab, responden pada kelompok kontrol dan perlakuan sebagian besar bisa menjawab dengan benar. Pada pertanyaan mengenai pengertian penyakit DM responden kelompok kontrol terdapat $45.3 \%$ dan kelompok perlakuan terdapat $43.8 \%$ menjawab karena kelebihan kadar gula darah, bahkan terdapat $14,1 \%$ dari kelompok perlakuan menjawab pengertian DM adalah penyakit karena kekurangan insulin. Data tersebut didukung dengan data penelitian mengenai pertanyaan penyebab penyakit DM, sebagian besar responden pada kelompok kontrol (92.2\%) dan pada kelompok perlakuan $(78.1 \%)$ menjawab penyakit DM disebabkan karena banyak makan/minum manis.

Jawaban yang benar pada pertanyaan mengenai pengertian dan penyebab penyakit DM bisa disebabkan responden mendapatkan informasi dari pelajaran di sekolah, majalah kesehatan, iklan layanan kesehatan dari media massa maupun elektronik. Selain itu bisa didapatkan dari pengalaman yang didapat dari keluarga atau saudara yang menderita DM. Karateristik responden berdasarkan riwayat DM pada keluarga, didapatkan sebagian besar responden pada kelompok kontrol $(62.5 \%)$ dan sebagian besar responden pada kelompok perlakuan $(67.2 \%)$. Hal ini sejalan dengan pendapat Notoatmodjo (2003) bahawa salah satu faktor yang mempengaruhi pengetahuan seseorang adalah pengalaman. Pengalaman seseorang dapat diperoleh dari pengalaman yang didapat diri sendiri maupun pengalaman dari orang lain. Adanya saudara atau keluarga yang menderita penyakit DM akan membuat remaja mendapat wawasan luas mengenai penyakit DM melalui melihat dan mendengar.

\section{Perubahan persepsi kelompok kontrol dan perlakuan}

Hasil analisis menunjukkan terdapat perbedaan yang signifikan terhadap peningkatan persepsi antara responden yang diberikan pendidikan 
kesehatan menggunakan leaflet dan responden yang diberikan pedidikan kesehatan menggunakan media audio visual berupa power point disertai film mengenai terjadi penyakit DM. Penggunaan media dalam pendidikan kesehatan sangat dibutuhkan. Menurut Levin \& Lentz dalam Dermawan, A.C (2008) media pembelajaran memiliki fungsi atensi yang memiliki kekuatan untuk menarik perhatian sasaran, fungsi afektif yaitu mempengaruhi sikap dan emosi, fungsi kognitif yaitu gambar atau simbol-simbol lain mempercepat pencapaian tujuan pendidikan kesehatan dengan mengingat gambar akan mempermudah proses pikir penerima pesan. Yang terakhir adalah fungsi kompensatori yaitu sebagai pelengkap dalam pemberian informasi.

Pendidikan kesehatan tentang faktor risiko DM tipe 2 pada kelompok kontrol dilakukan dengan menggunakan media leaflet yang berisi materi mengenai definisi, penyebab, faktor risiko, tanda gejala dan komplikasi. Setelah dilakukan analisis lebih lanjut didapatkan hasil ada perbedaan signifikan terhadap peningkat persepsi sebelum dan sesudah dilakukan pendidikan kesehatan dengan $\mathrm{p}=0.000$ ( $\mathrm{p}$ value < 0,05). Hasil tersebut menunjukkan pendidikan kesehatan menggunakan leaflet efektif untuk meningkatkan persepsi seseorang tentang faktor risiko DM tipe 2.

Pada kelompok kontrol pendidikan kesehatan menggunakan leaflet atau media tulisan dan gambar. Menurut Ergar Dale dalam Notoatmodjo (2007) media dalam pendidikan kesehatan menggunakan tulisan menempati urutan kedua pada kerucut teratas, artinya intensitas untuk diterima pesan atau materi pendidikan sedikit. Menurut Ellis \& Hartley (1998) menyatakan bahwa penerimaan informasi melalui pendengaran hanya dapat diserap 20\% saja. Walaupun pada kelompok perlakuan menggunakan leaflet dengan dipadukan teknik ceramah tanya jawab akan memberikan hasil yang baik. Pengetahuan meningkat, dengan pengetahuan yang baik maka persepsi responden tentang faktor risiko DM tipe 2 juga akan meningkat.

Ditinjau dari media yang digunakan dalam penelitian ini penggunaan audio visual lebih efektif dibandingkan menggunakan leaflet. Pada kelompok perlakuan diberikan pendidikan kesehatan menggunakan media audio visual berupa slide power point yang disertai gambar dan film animasi mengenai terjadinya DM dengan durasi 40 menit. Menurut Dermawan, A.C (2008) media audio visual merupakan media yang dihasilkan melalui proses mekanik dan elektronik dengan menyajikan informasi atau pesan secara audio dan visual. Media tersebut memberikan stimulus terhadap pandangan dan pendengaran, menyajikan visual yang dinamis, dirancang, menyampaikan pesan atau topik.

Penggunaan media audio visual maka penerima pesan akan tertarik dan termotivasi untuk memperhatikan dan mendapatkan stimulus secara audio dan visual dengan adanya gambar yang bergerak secara dinamis. Pencapain penerimaan pesan akan lebih banyak, dari Kerucut Edgar Dale (Dermawan, A.C, 2008) penggunaan film dalam media pendidikan kesehatan menempati urutan keempat dari kerucut teratas. Apabila dibandingkan dengan media leaflet yang berupa tulisan maka intensitas pesan yang diterima lebih banyak media film. Disampaikan juga menurut penelitian para ahli, indra yang paling banyak menyalurkan pengetahuan ke otak adalah mata. Kurang lebih $75 \%$ sampai $87 \%$ dari pengetahuan manusia diperoleh/disalurkan melalui mata. Sedangkan $13 \%$ sampai $25 \%$ lainnya tersalurkan melalui indra yang lain.

Menggunakan media film animasi menjadi lebih menarik, sesuai yang disampaikan Notoatmodjo (2003) dan Dermawan (2008) media tersebut akan mendorong keinginan orang untuk mengetahui, kemudian lebih mendalami, dan akhirnya mendapatkan pengertian yang baik. Orang yang melihat sesuatu yang memang diperlukan maka akan menarik perhatiaanya, dan apa yang diliat dengan penh perhatian akan memberikan pengertian baru bagai rang tersebut dan mendorong untuk melakukan atau memakai sesuatu yang baru tersebut. Dengan kata lain dengan melihat film animasi mengenai terjadinya penyakit DM maka remaja akan semakin paham faktor risiko terjadi DM dan persepsi akan meningkat sehingga bisa diharapkan akan merubah gaya hidup yang mengarah menuju faktor risiko DM tipe 2.

Karakteristik responden yang mendukung terhadap hasil penelitian diatas, adalah 
pengetahuan tentang penyakit DM meliputi pengertian, dan penyebab penyakit DM yang dimiliki sebelum dilakukan pendidikan kesehatan sudah baik. Dengan pengetahuan awal yang baik, kemudian diberikan pendidikan kesehatan menggunakan media yang sesuai dan menarik akan membantu mengakkan pengetahuan-pengetahuan yang telah diterima sehingga akan lebih lama tersimpan (Notoatmodjo, 2007). Brewer, et al dalam Saikani (2009) dalam disertasinya mengenai Perceived Risk For Cardiovascular Disease And Diabetes Type 2 Among Samoans With Metabolic Syndrome menyampaikan bahwa faktor kognitif merupakan faktor berperan dalam membentuk perilaku antara lain : sikap, persepsi dan pengetahuan.

Faktor yang lain adalah pengalaman, pada kelompok kontrol dan perlakuan sebagian besar keluarga atau saudara ada yang menderita DM. Hal tersebut akan membuat remaja memiliki pengalaman tentang penyakit DM. Pengalaman memberikan kontribusi yang cukup terhadap persepsi seseorang. Rahmat (2000) dalam Marliya, Dewi \& Suyasa (2004) menyampaikan persepsi dibentuk dari penyimpulan informasi dan penafsiran kesan dari pengalaman akan obyek, peristiwa dan hubungan-hubungan yang diperoleh. Sehingga dapat disimpulkan persepsi juga dipengaruhi oleh konteks, pengalaman masa lalu dan ingatan.

\section{SIMPULAN DAN SARAN}

Pendidikan kesehatan tentang faktor risiko DM tipe 2 dengan media audio visual efektif meningkatkan persepsi remaja yang ditunjukkan terdapat perbedaan peningkatan rata-rata persepsi setelah diberikan pedidikan kesehatan menggunakan media audio visual antara kelompok kontrol (39.84) dan kelompok perlakuan (41.57) dengan $\mathrm{p}$ value $=0.002$

Perlu meningkatkan persepsi remaja melalui pendidikan kesehatan dengan media atau metoda interaktif sehingga bisa lebih menarik minat dan meningkatkan motivasi untuk merubah gaya hidup yang mengarah ke faktor risiko DM tipe baik di lingkungan sekolah maupun luar sekolah. Lembaga pendidikan atau sekolah menyediakan lingkungan yang mendukung ke arah gaya hidup yang sehat dengan cara memasukkan kegiatan aktifitas fisik dan pola nutrisi yang sehat dalam lingkungan sekolah. Mengembangkan tindakan keperawatan dalam pencegahan DM tipe 2 melalui pemberian pendidikan kesehatan dengan berbagai macam sasaran baik individu, kelompok maupun masyarakat dengan menggunakan metode dan media yang sesuai.

\section{DAFTAR RUJUKAN}

Arikunto, S. (2002). Prosedur penelitian suatu pendekatan praktek. Jakarta: PT. Rineka Cipta.

Dempsey, P.A., \& Dempsey, A.D. (2002). Riset keperawatan: Buku ajar dan latihan. Jakarta: EGC.

Dunning, T. (2003). Care of People with Diabetes : A Manual of Nursing. $2^{\text {nd }}$ ed. Malden: Blackwell Publishing.

Ignatavicius, D.D., \& Workman, M.L. (2006). Medical Surgical Nursing. $5^{\text {th }}$ Ed. St. Louis, Missouri: Elsevier Saunders

Lemeshow, S., Hosmer, D.W., Klar, J., \& Lwanga, S.K. (1997). Besar Sampel Dalam Penelitian Kesehatan. Yogyakarta. Gajah Mada University Press

LeMone, P., \& Burke, K. (2008). Medical Surgical Nursing Critical Thinking in Client Care. $4^{\text {th }} E d$. Canada: Pearson Education, Inc

Lewis, S.M., Heitkemper, M.M.L., Dirksen, S.R. (2000). Medical surgical nursing: Assesment and management of clinical problem. $5^{\text {th }}$. ed., St. Louis: Mosby, Inc.

Notoatmodjo, S. (2003). Pendidikan dan Perilaku Kesehatan. Jakarta : PT. Rineka Cipta

Notoatmodjo, S. (2007). Kesehatan Masyarakat Ilmu \& Seni. Jakarta : Rineka Cipta.

Notoatmodjo, S. (2007). Promosi kesehatan \& ilmu perilaku. Jakarta : Rineka Cipta

Persi. (2008). Faktor Lingkungan dan Gaya Hidup Berperan Besar Memicu Diabetes. http://www.pdpersi.co.id/?show=detailne $w s \& k o d e=914 \& t b l=k e s l i n g$, diperoleh 16 Oktober 2008.

Potter, P., A., \& Perry, A., G. (2005). Buku ajar fundamental keperawatan : Konsep, proses, dan praktik. Jakarta : EGC 
Price, S.A., \& Wilson M.W, (1995). Patofisiologi konsep klinik proses-proses penyakit, Ed 2. Jakarta: EGC

Rudijanto, A.(2010). Pencegahan dan Penatalaksanaan Diabetes Mellitus melalui Pendekatan Komunitas. Disampaikan dalam Pidato Pengukuhan Jabatan Guru Besar dalamIlmu Penyakit Dalam-Endokrin pada Fakultas Kedokteran Universitas Brawijaya. Malang

Setiawati, S \& Dermawan, A.C. (2008). Proses Pembelajaran dalam Pendidikan Kesehatan. Jakarta: Trans Info Medika

Siaki, L.A.C.L.G. (2009). Perceived Risk For Cardiovascular Disease And Diabetes Type 2 Among Samoans With Metabolic Syndrome

Silbernagl, S., \& Lang, F. (2007). Teks \& atlas berwarna patofisiologi. Jakarta: EGC

Smeltzer, S.C., Bare, B.G., Hinkle, JL., Cheever, K.H. (2008). Brunner \& Suddarth"s: Textbook of medical-surgical nursing. $11^{\text {th }}$ ed. Philadelphia: Lippincott Williams \&Wilkins.

Soegondo, S., Soewondo, P., Subekti, I. (2009). Penatalaksanaan Diabetes Melitus Terpadu. Jakarta: Balai Penerbit FKUI.

Soegondo, S., Soewondo, P., Subekti, I., Oemardi, M., Semiardji, G. \& Soebardi, S. (2002). Petunjuk Praktis Pengelolaan Diabetes Melitus Tipe 2. Jakarta : PB Perkeni.

Soegondo, S., Rudianto, A., Manaf, A., Subekti, I., Pranoto, A., Arsana, P.M., et al. (2006). Konsensus Pengelolaan dan Pencegahan Diabetes Melitus Tipe 2 di Indonesia 2006. Jakarta : PB Perkeni.

Sudoyo, A.W., Setiyohadi, B., Alwi, I., Simadibrata, M., Setiati, S. (2006). Buku ajar ilmu penyakit dalam. Jakarta: Pusat penerbitan Departemen Ilmu Penyakit Dalam FKUI.

Suliha, U., Herawani, Sumiati, \& Resnayati, Y. (2002). Pendidikan kesehatan dalam keperawatan. Jakarta : EGC 